\title{
Kinetics of Gas Emissions from Moulding and Core Sands, Gasification Patterns and Protec- tive Coatings - the New Investigation Method
}

Jerzy Zych, Jan Mocek

AGH University of Science and Technology, Faculty of Foundry Engineering, Reymonta 23, 30-059 Kraków, Poland, Correspondence address: e-mail: jzych@agh.edu.pl

Gases evolving from moulds, cores, coatings deposited on sand and metal moulds constitute one of the basic reasons of several casting surface defects: blow-holes, pinholes, pitted skin, etc. In research performed up to now the moulding sands gas evolution is determined in two ways: normalised, in which the gas amount emitted from the sample placed in a heated flask is determined or in the other way, in which the gas amount emitted from the core - covered with liquid metal - is determined. In these both methods the result constitutes the total amount of gases emitted from $1 \mathrm{~g}$ of a moulding sand and the emission procedure as a time function. The new method of investigating the kinetics of gases evolution from moulding sands (and coatings), applied for making moulds, is presented in this paper. The kinetics is tested not only as the heating time function but also as the temperature function. The method was developed in the Department of Mould Technology of the Faculty of Foundry Engineering, AGH. Amounts of gases emitted from the moulding sand at the given temperature in the time unit are obtained in investigations. The results of testing the group of moulding sands (furan, alkide, moulding sands with water glass) and the group of protective coatings applied for sand and metal moulds, are presented in this paper.

Keywords: Gas Evolution, Moulding Sands, Expanded Polystyrene, Protective Coatings

\section{Acknowledgement}

Research was carried out within the project NCBiR: Nr PBS3/B5/47/2015

\section{References}

[1] LEWANDOWSKI, J. L. (1997). Tworzywa na formy odlewnicze, Kraków 1997.

[2] LEWANDOWSKI, J. L., SOLARSKI, W., PAWŁOWSKI, Z. (1993). Klasyfikacja mas formierskich $i$ rdzeniowych pod względem gazotwórczości. Przegląd Odlewnictwa. Nr 51993.

[3] URBANIK, E. (1964). Praca doktorska, AGH, Wydział Odlewnictwa Kraków. 1964.

[4] HOLTZER, M., DAŃKO, J., LEWANDOWSKI, J. L., i inni., (2013). Station for research of the volume and harmfulness of gases compounds from the materials used in foundry and metallurgical processes] . AGH. Polska.;PL 398709 A1. Zgłosz. 2012-04-02; Biuletynyn Urzędu Patentowego; ISSN: 0137-8015;2013 nr21, s. 26.

[5] HOLTZER M, DAŃKO R., DAŃKO J., KUBECKI M, ŻYMANKOWSKA - KUMON S, BOBROWSKI A, ŚPIEWOK W. (2013). Praca zbiorowa -,,Ocena szkodliwości materiatów wiązacych stosowanych do mas formierskich $i$ rdzeniowych nowej generacji. AGH Akademia Górniczo-Hutnicza im. Stanisława Staszica w Krakowie. Kraków: Wydawnictwo Naukowe Akapit, 2013.

[6] HOLTZER, M., i inni. (2012). Badania emisji niebezpiecznych związków z mas z bentonitem i nośnikami węgla błyszczącego w kontakcie z ciekłym metalem. Przeglad Odlewnictwa. 2012, Tom 62, 3-4, 124-132.

[7] MOCEK, J., ZYCH, J., KRUBNIK, Ł. (2014). Wybrane zagadnienia odlewania stopów Al - Si w technologii pełnej formy, Kraków - Starachowice: XVII Międzynarodowa Konferencja Naukowo - Techniczna Odlewnictwa Metali Nieżelaznych, 2014.

[8] ZYCH, J., MOCEK, J., SNOPKIEWICZ, T. (2014). Gas generation properties of materials used in the sand mould technology - modified research method, Archives of Foundry Engineering, (2014), vol. 14 iss. 3/2014 s. 105-109.

[9] BATES, CH., LITTLETON, H., STROOM, P., MCMELLON, B. (2000). Technological Developments and Worlwide Market Growth in Lost Foam Casting Production. 64th World FoundryCongress, Paris 2000. Referat UA 72.

[10] BOLIBRUCHOVÁ, D., RICHTÁRECH, L. (2013). Study of the gas content in aluminum alloys, Manufacturing Technology, (2013), Vol.13, No.1, s.14-20.

[11] VASKOVÁ, I., JANČOK, J., HRUBOVČÁKOVÁ, M., CONEV, M. (2015). Hydrogen Removal from Liquid Metal, Manufacturing Technology, (2015), Vol. 15, No.4, s.737-739.

[12] HONZÁTKO, R., MICHNA, Š., CAIS, J. (2013). The Influence of Porosity on Mechanical Properties of Casts Produced from Al - Si Alloys, (2013) Vol.13, No.3, s.319-324. 